\title{
SYNTHESIS OF Ni/MESOPOROUS SILICA-ALUMINA USING SIDOARJO MUD AND BOVINE BONE GELATIN TEMPLATE FOR HYDROCRACKING OF WASTE LUBRICANT
}

\author{
W. Trisunaryanti ${ }^{1, *}$, I. I. Falah ${ }^{1}$, D. R. Prihandini ${ }^{1}$ and M. F. Marsuki ${ }^{2}$ \\ ${ }^{1}$ Department of Chemistry, Universitas Gadjah Mada, 55281, Yogyakarta, Indonesia \\ ${ }^{2}$ Study Program of Sciences Education, Universitas Negeri Malang, 651145, Malang, Indonesia \\ *E-mail : wegats@ugm.ac.id
}

\begin{abstract}
Synthesis of Ni/mesoporous silica-alumina (MSA) with silica from Sidoarjo mud using bovine bone gelatin as a template and its activity for hydrocracking of waste lubricant have been investigated. Nickel was loaded onto MSA using wet impregnation (WI) and ion exchange (IE) method. MSA-100 has optimum thermal stability, the acidity of $72.89 \mathrm{mmol} / \mathrm{g}$, the pore diameter of $3.37 \mathrm{~nm}$, the surface area of $230.73 \mathrm{~m}^{2} / \mathrm{g}$, and a pore volume of $0.87 \mathrm{~cm} / \mathrm{g} . \mathrm{Ni}$ content of MSA-100 (WI) and (IE) was 0.48 and 0.08 wt.\%, respectively. Ni/MSA-100(IE) produced the highest amount of liquid with gasoline and diesel content of 49.05 and 14.09 wt.\% on hydrocracking of waste lubricant.
\end{abstract}

Keywords: Silica-alumina, Mesoporous, Hydrocracking, Waste Lubricant, Gelatin

(C) RASĀYAN. All rights reserved

\section{INTRODUCTION}

The waste lubricant was contained heteroatom of poly-aromatic compounds. These poly-aromatic compounds were considered as toxic compounds for environmental. Upgrading of waste lubricant into fuel is an effective way to prevent environmental pollution from disposal of waste lubricant ${ }^{1}$. Nickel metal had been reported as a high activity catalyst for hydrocracking reaction ${ }^{2}$. However, the application of Ni metal directly as a catalyst is not effective because sintering and agglomeration often occur along the hydrocracking process. The sintering and agglomeration of metal can be prevented by impregnation of the metal onto support material that has a high surface area such as mesoporous materials.

The research of mesoporous material has attracted attention due to the properties of mesoporous material such as porosity, high surface area, chemical stability and wide applications for adsorbent, catalyst or catalyst support such as MCM- $41^{3}$, SBA- $15^{4}$, mesoporous carbon ${ }^{5}$, and mesoporous silica ${ }^{6}$.

Mesoporous silica can be synthesized from various silica sources such as tetraethyl orthosilicate (TEOS) and sodium silicate ${ }^{3}$. As an alternative, mesoporous silica can also be synthesized from silica extracted from natural source ${ }^{7}$. Al Ifah et $\mathrm{al}^{3}$ reported that MCM-41 had been successfully synthesized using silica from Sidoarjo mud and gelatin extracted from bovine bone as a mold or template.

The catalyst that is used for hydrocracking reaction should have high acidity. Transition metals play an important role in acidity properties of catalysts by providing acid sites ${ }^{8}$. However, mesoporous silica as support material has only weak acid sites.

Therefore, the addition of $\mathrm{Al}$ atom in the framework of mesoporous silica can increase the acidity. High acidity mesoporous silica-alumina (MSA) was more potential than that of mesoporous silica to be used as catalyst support for hydrocracking reaction.

In present work, Ni metal was loaded on mesoporous silica-alumina synthesized using silica from Sidoarjo mud and bovine bone gelatin.

The loading of Ni metal was carried out using a wet impregnation (WI) and ion exchange (IE) method. The effect of Ni metal loading method toward catalytic activity and selectivity for gasoline and diesel production was evaluated.

Rasayan J. Chem., 12(3), 1523-1529(2019)

http://dx.doi.org/10.31788/RJC.2019.1235297

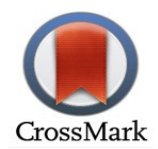




\section{EXPERIMENTAL}

The mud was collected from Sidoarjo Regency. Bovine bone was collected from Yogyakarta local market. $\mathrm{NaOH}, \mathrm{HCl}, \mathrm{Al}_{2} \mathrm{O}_{3} \cdot \mathrm{Na}_{2} \mathrm{O}, \mathrm{NiCl}_{2} \cdot 6 \mathrm{H}_{2} \mathrm{O}, \mathrm{CH}_{3} \mathrm{COOH}$, and $\mathrm{H}_{2} \mathrm{SO}_{4}$ were analytical grade and purchased from Merck (Germany).

\section{Instrumentation}

Surface area analyzer (Quantachrome NovaWin Series) was utilized to determine the surface parameters (surface area, pore-volume, and pore diameter) of the samples. The determination was based on physical adsorption of $\mathrm{N}_{2}$ gas on pores of the material at $77.3 \mathrm{~K}$. Pore images of material were taken using TEM (JEOL JEM-1400) at accelerating voltage of $120 \mathrm{kV}$. The functional groups of the samples were determined using FTIR spectroscopy (Shimadzu Prestige-21) which is equipped with data station in the range of $400-400 \mathrm{~cm}^{-1}$ with a $\mathrm{KBr}$ disc technique. The pore disruptors in the samples were removed by the evaporating process at $300^{\circ} \mathrm{C}$ for $3 \mathrm{~h}$. The produced liquid from hydrocracking of waste lubricant was analyzed using GC-MS (Shimadzu QP2010S) with a column diameter of $0.25 \mathrm{~mm}$, length of $30 \mathrm{~m}$, the thickness of $0.25 \mu \mathrm{m}, \mathrm{He}$ as a carrier gas, the temperature of $60-310^{\circ} \mathrm{C}$, and acceleration voltage of $70 \mathrm{Ev}$.

\section{Extraction of Silica from Sidoarjo Mud}

Sidoarjo mud was dried at $100^{\circ} \mathrm{C}$ and sifted to 100 mesh. The mud was refluxed with $6 \mathrm{M} \mathrm{HCl}$ solution at $90^{\circ} \mathrm{C}$ for $3 \mathrm{~h}$. The residue of mud was rinsed with demineralized water and refluxed again with $6 \mathrm{M}$ $\mathrm{NaOH}$ solution for $16 \mathrm{~h}$ at $90^{\circ} \mathrm{C}$. The filtrate was titrated using $3 \mathrm{M} \mathrm{HCl}$ solution until the acidity reached $\mathrm{pH}$ 8. The solid formed on the filtrate was filtered, rinsed with demineralized water, and dried at $100 \square$ for $24 \mathrm{~h}$. The $\mathrm{SiO}_{2}$ was analyzed by FTIR spectroscopy.

\section{Extraction of Gelatin}

Bovine bone was cleaned and rinsed with demineralized water. The bovine bone was soaked in $4 \%$ acetic acid solution (1:2, w/v) for 3 days. The bovine bone was then pretreated with $0.1 \mathrm{M} \mathrm{NaOH}$ solution for 24 $\mathrm{h}$ and $1.0 \mathrm{M} \mathrm{HCl}$ solution for $1 \mathrm{~h}$. The pretreated bovine bone was refluxed with demineralized water at $70^{\circ} \mathrm{C}$ for $5 \mathrm{~h}$. The filtrate was dried at a temperature of $50^{\circ} \mathrm{C}$ and the formed gelatin was analyzed by FTIR spectroscopy.

\section{Synthesis of Mesoporous Silica-Alumina (MSA)}

The bovine bone gelatin was dissolved in demineralized water. The gelatin solution was stirred and heated at $40^{\circ} \mathrm{C}$ for $30 \mathrm{~min}$. The gelatin solution was added with $\mathrm{Al}_{2} \mathrm{O}_{3} \cdot \mathrm{Na}_{2} \mathrm{O}$ and stirred for $30 \mathrm{~min}$ (solution 1). In another beaker, $\mathrm{SiO}_{2}$ was dissolved in $1.5 \mathrm{M} \mathrm{NaOH}$ solution (mole ratio of 1:2) to form a sodium silicate solution. The sodium silicate solution was stirred and heated at $40{ }^{\circ} \mathrm{C}$. The acidity of sodium silicate solution was adjusted to $\mathrm{pH} 4$ by addition of $0,1 \mathrm{M} \mathrm{H}_{2} \mathrm{SO}_{4}$ solution (solution 2). The solution 2 was dropwise added to the solution 1 and the mixture was stirred for $24 \mathrm{~h}$. The formed gel solution was hydrothermally treated at $100^{\circ} \mathrm{C}$ for $24 \mathrm{~h}$. The formed solid was filtered, rinsed with demineralized water, dried at $80^{\circ} \mathrm{C}$ over night, and heated at $550{ }^{\circ} \mathrm{C}$ for $5 \mathrm{~h}$. The MSA was analyzed by TEM, GSA, and FTIR. MSA synthesized in this work had a Si/Al mole ratio of 25, 50, and 100.

\section{Acidity Determination}

The acidity of the MSA and Ni/MSA catalyst was determined by addition of the ammonia gas stream into the sample at vacuum condition at room temperature for $24 \mathrm{~h}$. The acidity value of the MSA and Ni/MSA catalyst was calculated using the following equation:

$$
\text { Acidity Value }=\frac{\text { weight of sample after adsorption }- \text { weight of sample before adsorption }}{\text { weight of sample before adsorption } \times \mathrm{Mr} \mathrm{NH}_{3}}
$$

\section{Loading of Ni Metal on MSA}

The Ni metal was loaded on the MSA using wet impregnation (WI) and ion exchange (IE) method. After loading, the catalysts were dried at $70^{\circ} \mathrm{C}$ for $24 \mathrm{~h}$. At the end of the metal loading process, the catalysts 
were reduced under $\mathrm{H}_{2}$ gas stream at $450^{\circ} \mathrm{C}$ for $3 \mathrm{~h}$. $\mathrm{NiCl}_{2}$ solution used in this work contains $\mathrm{Ni}$ metal of $1.00 \mathrm{wt} \%$. Amount of Ni metal loaded on the MSA was analyzed by ICP.

\section{Catalyst Activity Test}

The catalysts activity test of the Ni/MSA were carried out using stainless steel microreactor of semi-batch system for hydrocracking of waste lubricant. The hydrocracking process was carried out under $\mathrm{H}_{2}$ gas stream $(10 \mathrm{~mL} / \mathrm{min})$ at $450^{\circ} \mathrm{C}$ for $3 \mathrm{~h}$. The catalyst/waste lubricant weight ratio was about $1 / 100$. The liquid products were analyzed using GC-MS.

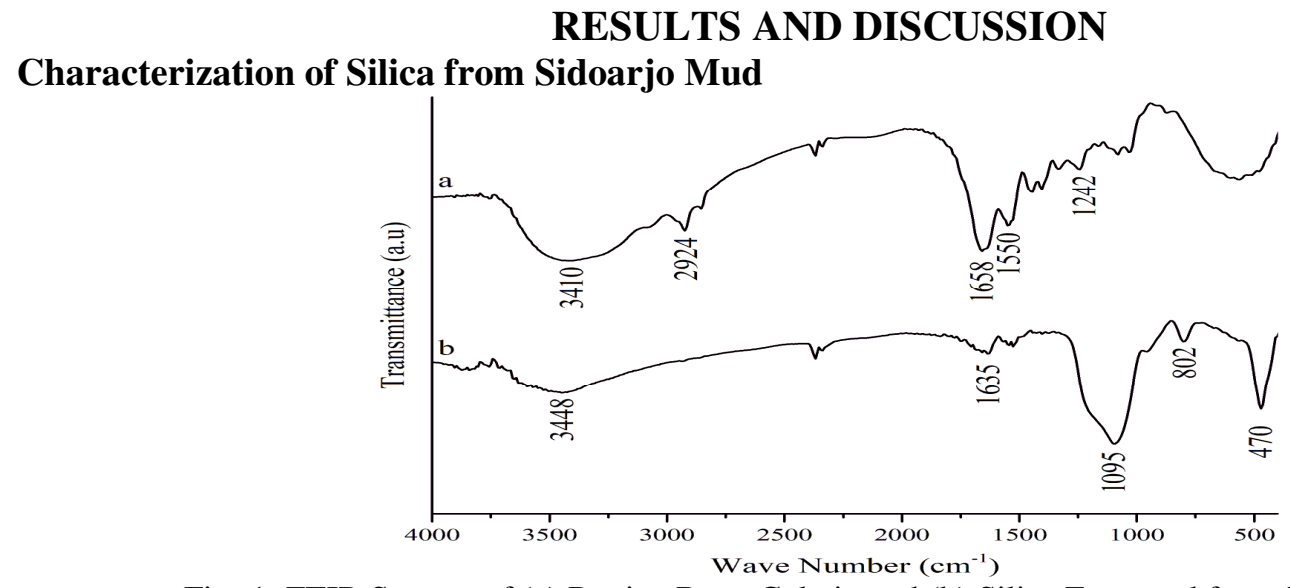

Fig.-1: FTIR Spectra of (a) Bovine Bone Gelatin and (b) Silica Extracted from Sidoarjo Mud

The FTIR spectra of silica extracted from Sidoarjo mud are presented in Fig.-1(b). In the general, absorption peaks appearing on the IR spectra of silica are silanol ( $\mathrm{Si}-\mathrm{OH})$ and siloxane group (Si-O-Si). The absorption peak at $470 \mathrm{~cm}^{-1}$ corresponds to bending vibration of Si-O-Si bond. The absorption peak at 1095 and $802 \mathrm{~cm}^{-1}$ correspond to the asymmetric and symmetric stretching vibration of $\mathrm{Si}-\mathrm{O}$ bond on silanol group 9 . Absorption peak, which corresponds to $\mathrm{O}-\mathrm{H}$ bond on silanol group, arise at $3448 \mathrm{~cm}^{-1}{ }^{10}$. The absorption peak at $1653 \mathrm{~cm}^{-1}$ refers to bending vibration of $\mathrm{H}-\mathrm{O}-\mathrm{H}$ bond from water molecule absorbed on the silica surface. Interpretation of the FTIR spectra in Fig. 1 indicates that silica had successfully extracted from the Sidoarjo mud.

\section{Characterization of Bovine Bone Gelatin}

Figure-1(a) presents FTIR spectra of bovine bone gelatin extracted in this work. Basically, IR spectra of gelatin have 5 absorption peaks of the amide group, namely amide A, amide B, amide I, amide II, and amide $\mathrm{III}^{11}$. The absorption peak at $3410 \mathrm{~cm}^{-1}$ is amide A and it refers to stretching vibration of $\mathrm{N}-\mathrm{H}$ and $\mathrm{O}-\mathrm{H}$ bonds. Absorption peak arises at $2924 \mathrm{~cm}^{-1}$ is amide $\mathrm{B}$ and it refers to stretching vibration of $\mathrm{CH}_{2}$. Amide I at $1658 \mathrm{~cm}^{-1}$ corresponds to stretching vibration of $\mathrm{C}=\mathrm{O}$ bond and bending vibration of $\mathrm{N}-\mathrm{H}$ bond. Amide II at $1550 \mathrm{~cm}^{-1}$ corresponds to stretching vibration of $\mathrm{CN}$ bond and bending vibration of $\mathrm{N}-\mathrm{H}$ bond. Amide III at $1242 \mathrm{~cm}^{-1}$ refers to deformation of $\mathrm{NH}$ from amide linkage and stretching vibration of $\mathrm{CN}^{12}$.

\section{Characterization of MSA}

Figure-2 present FTIR spectra of MSA-25, MSA-50, and MSA-100 before and after calcination. Absorption peaks at 2924 (amide B) and $1550 \mathrm{~cm}^{-1}$ (amide III) on FTIR spectra of uncalcined MSA samples indicated that the bovine bone gelatin still remained on the MSA framework ${ }^{13}$. However, these absorption peaks had disappeared on FTIR spectra of calcined MSA samples. This phenomenon means that the calcination process in this work was effective to remove the bovine bone gelatin from the MSA framework.

Absorption peaks indicating as typical peaks of silica-alumina appear at $3441-3448 \mathrm{~cm}^{-1}$ (stretching vibration of Si-OH bond), $1627-1658 \mathrm{~cm}^{-1}$ (bending vibration of $\mathrm{Si}-\mathrm{OH}$ bond), $1064-1080 \mathrm{~cm}^{-1}$ (stretching 
vibration of T-O-T bond, where $\mathrm{T}$ is $\mathrm{Si}$ or $\mathrm{Al}$ ), $570-578 \mathrm{~cm}^{-1}$ (bending vibration of Si-O-Al bond) ${ }^{14}$. After the calcination process, the absorption peak of stretching vibration of T-O-T bond on MSA-25 and MSA50 shifted to $1080 \mathrm{~cm}^{-1}$. This absorption peak is related to the stability of MSA framework ${ }^{15}$. The shifting of the absorption peak of stretching vibration of T-O-T indicates thermal stability of MSA-25 and MSA50 are lower than MSA-100.
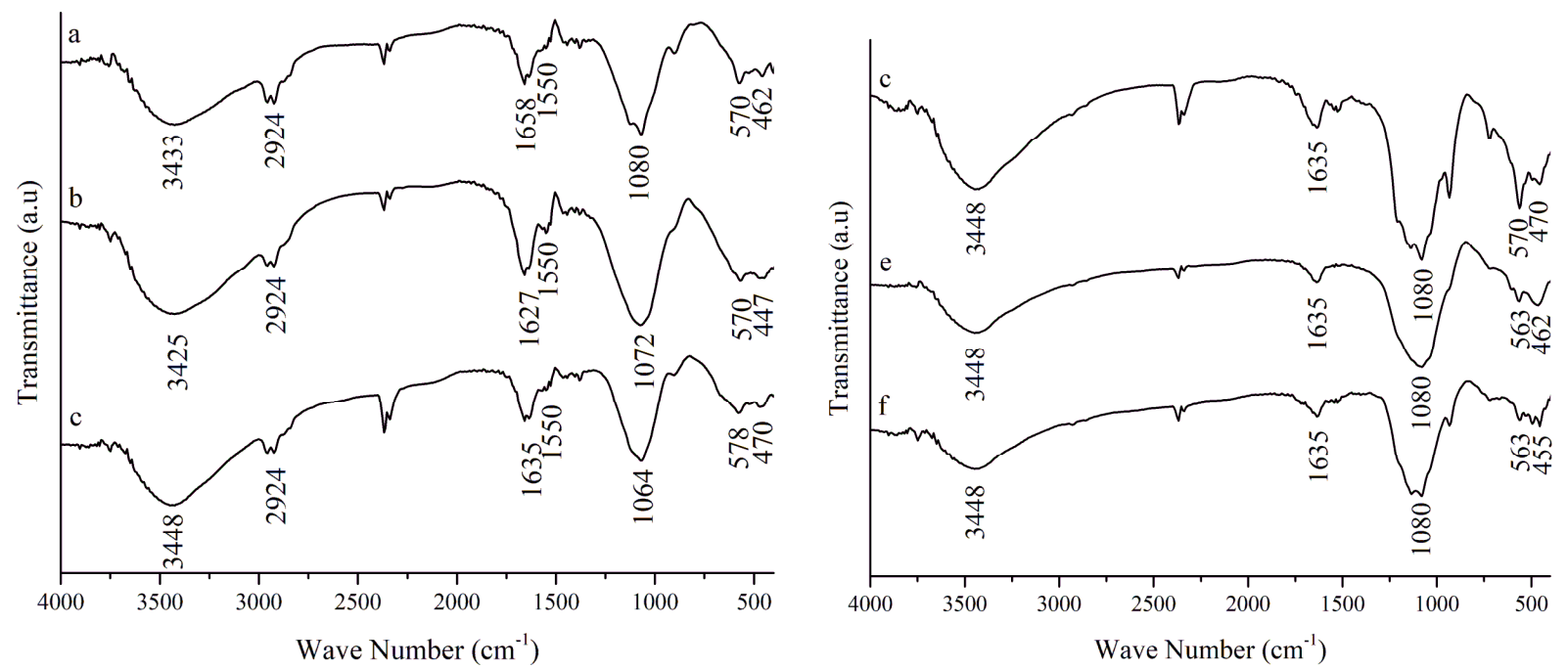

Fig.-2: FTIR Spectra of (a) MSA-100, (b) MSA-50, (c) MSA-25, (d) Calcined MSA-100, (e) Calcined MSA-50, and

(f) Calcined MSA-25

Table-1: The Acidity of MSA Samples

\begin{tabular}{c|c}
\hline Sample & Acidity $(\mathrm{mmol} / \mathrm{g})$ \\
\hline MSA-25 & 49.08 \\
\hline MSA-50 & 34.54 \\
\hline MSA-100 & 72.89 \\
\hline
\end{tabular}

Table-1 presents the acidity of the MSA. The acidity of MSA was determined gravimetrically by the adsorption method of ammonia vapor at vacuum condition. The highest acidity is obtained by MSA-100. It indicates that MSA-100 is better to be utilized as support material for Ni metal catalyst than MSA-25 and MSA $-50^{16}$. Moreover, MSA-100 has the highest thermal stability. These properties were used as the basis for choosing MSA-100 as support material.
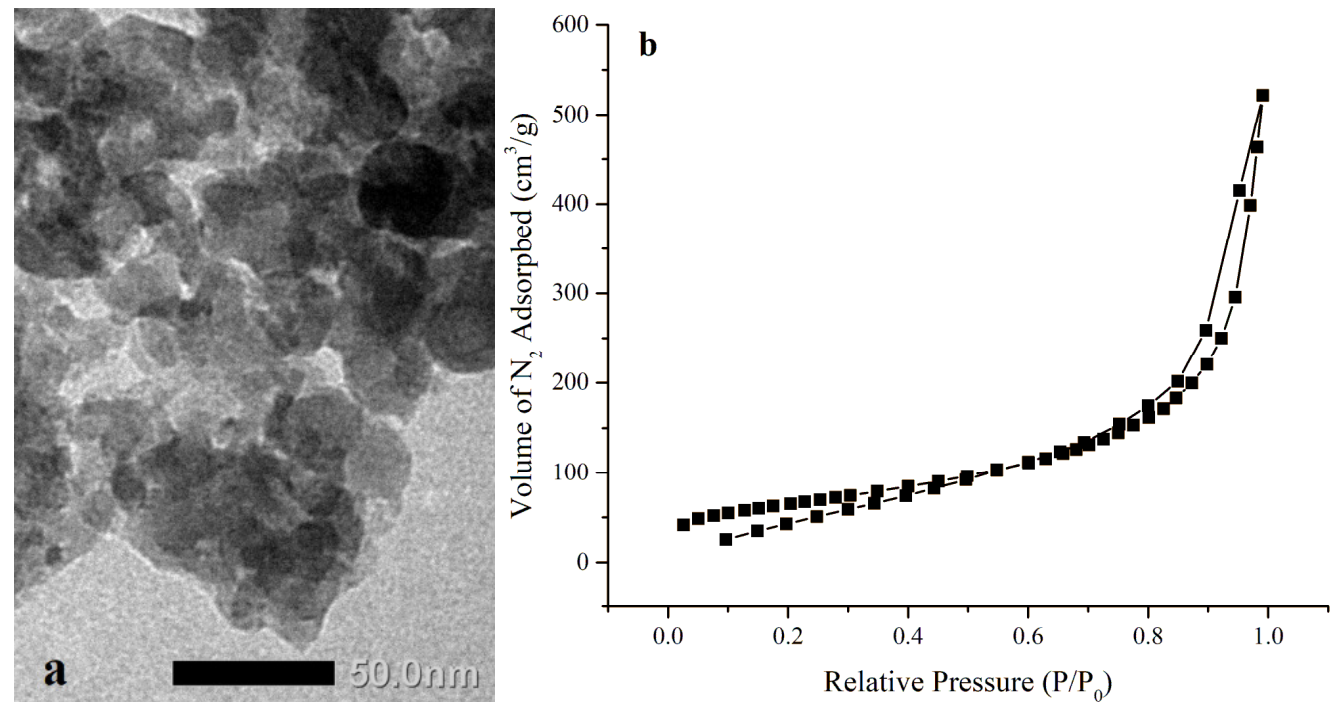

Fig.-3: (a) TEM Micrograph of MSA-100 and (b) Isotherm Sorption of $\mathrm{N}_{2}$ on MSA-100 
A TEM micrograph of MSA-100 is presented in Figure-3(a). The TEM micrograph indicates that the pore size of the synthesized MSA in this work is not uniform. It is because bovine bone gelatin used on the synthesis of MSA has wide molecular weight range ${ }^{17}$. Figure-3(b) presents adsorption-desorption isotherm of $\mathrm{N}_{2}$ on MSA-100. The isotherm pattern is indicated as type IV isotherm and the hysteresis type of MSA-100 can be classified as H3 type, which is typical of mesoporous material according to the IUPAC classification. The MSA material has BJH desorption pore diameter of $3.37 \mathrm{~nm}$, BET surface area of $230.73 \mathrm{~m}^{2} / \mathrm{g}$, and a total pore volume of $0.87 \mathrm{~cm}^{3} / \mathrm{g}$. The result indicates that bovine bone gelatin has played a role as a non-ionic template to form the MSA.

\section{Characterization of Ni/MSA-100 Catalyst}

The Ni metal was loaded onto MSA-100 using wet impregnation (WI) and ion exchange (IE) method to produce Ni/MSA-100 (WI) and Ni/MSA-100 (IE) catalysts. Amount of Ni metal on MSA-100 was analyzed by ICP. The Ni metal loaded on the MSA-100 by WI method was $0.48 \mathrm{wt} \%$ and IE method was 0.08 wt.\%. The acidity of the Ni/MSA-100 (WI) and Ni/MSA-100 (IE) were 89.35 and $79.55 \mathrm{mmol} / \mathrm{g}$, respectively. The Ni/MSA-100 (WI) catalyst has the highest acidity because the amount of Ni metal loaded onto Ni/MSA-100 using WI method is higher than using IE method. The Ni metal has empty of half-filled $d$ orbital, which can bind nonbonding electron pair from ammonia. It means that the Ni metal will increase Lewis acid sites of the MSA- $100^{18}$.

\section{Activity Test of the Ni/MSA-100 Catalyst

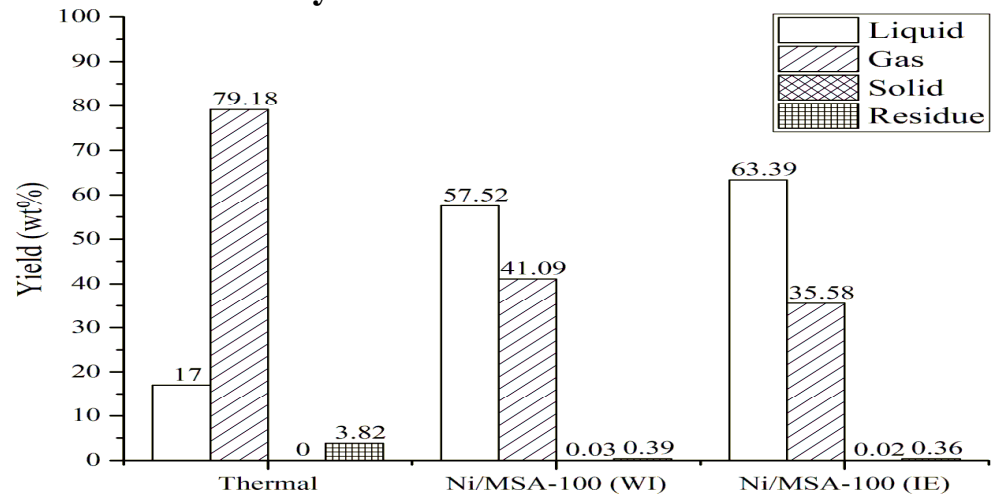 \\ Fig.-4: The Product Distribution of Hydrocracking of Waste Lubricant}

Catalysts activity test were carried out using catalysts synthesized in this work as well as thermal hydrocracking. Products distributions of the hydrocracking of waste lubricant was presented in Fig.-4. The highest quantity of liquid product was produced in the hydrocracking of waste lubricant using Ni/MSA-100(IE) catalyst, while the lowest quantity of liquid product was produced in the thermal hydrocracking of waste lubricant. This result makes sense because the thermal hydrocracking was taken place via a free radical mechanism that can produce more gas product than liquid product ${ }^{19}$. The increase of the quantity of a liquid product in hydrocracking of waste lubricant using the catalysts can be explained due to their acidic properties. The catalysts synthesized in this work have Lewis acid sites from the Ni metal and BrØnsted acid sites of the MSA. These acid sites were able to hydrocrack the waste lubricant via carbonium intermediate. Initiation of hydrocracking reaction can occur by proton addition (BrØnsted acid) or removing hydrogen anion by Lewis acid that can convert olefinic linkage into an on-chain carbonium $^{20}$. The carbonium chain might be broken up and form short-chain hydrocarbon compounds. These short-chain hydrocarbon compounds can be a gas product $\left(\mathrm{C}_{1}-\mathrm{C}_{4}\right)$, gasoline $\left(\mathrm{C}_{5^{-}}-\mathrm{C}_{12}\right)$, diesel $\left(\mathrm{C}_{13^{-}}\right.$ $\left.\mathrm{C}_{18}\right)$ or others $\left(>\mathrm{C}_{18}\right)$.

In Fig.-5, it can be observed that hydrocracking of waste lubricant using the catalysts produced a higher amount of fuel fraction (gasoline and diesel) than thermal hydrocracking. The highest amount of gasoline and diesel was obtained by using Ni/MSA-100(IE) catalyst. According to the acidity test result, Ni/MSA100 (WI) catalyst has a higher acidity property than Ni/MSA-100(IE). It leads to the fact that further cleavage of fuel product (gasoline and diesel) had happened and more gas product was obtained by using 
Ni/MSA-100(WI) catalyst. This statement can be used to explain the highest selectivity of Ni/MSA100(IE) catalyst in gasoline and diesel production.

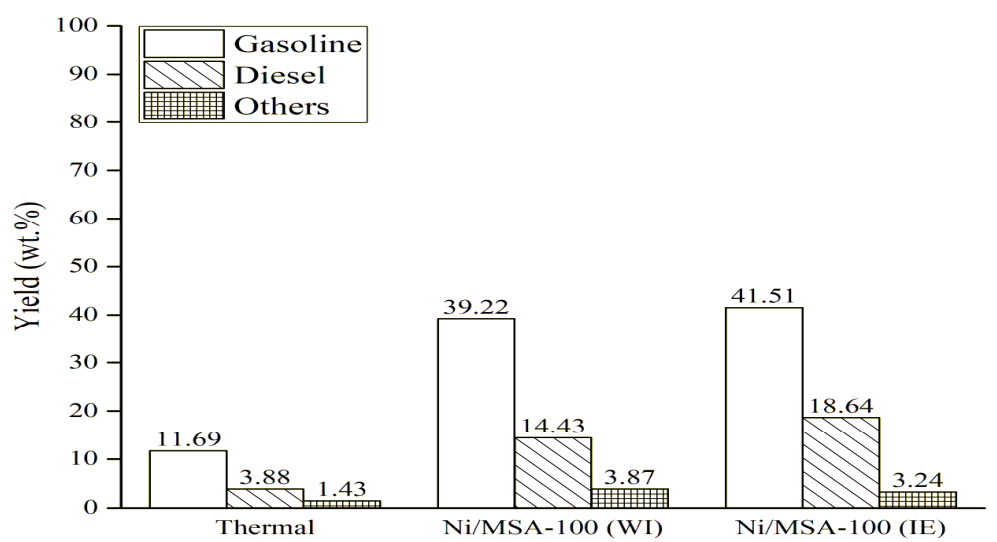

Fig.-5: Catalysts Selectivity towards Gasoline and Diesel Product

\section{CONCLUSION}

The conversion process of waste lubricant into fuel product (gasoline and diesel) depends on the acidity of the catalyst. The Ni/MSA-100(IE) catalyst has optimum acidity with the highest selectivity for gasoline and diesel products in hydrocracking of waste lubricant. Hydrocracking of waste lubricant using Ni/MSA100(IE) catalyst produced gasoline and diesel fraction of 41.51 and $18.64 \mathrm{wt} \%$, respectively.

\section{ACKNOWLEDGMENT}

This research work was supported by the Faculty of Mathematics and Natural Sciences, Universitas Gadjah Mada, Yogyakarta, Indonesia (Contract number: 0036/J01.1.28/PL.06.02/2017).

\section{REFERENCES}

1. Nurmalasari, W. Trisunaryanti, Sutarno and I. I. Falah, Int. J. ChemTech Res., 9, 607(2016).

2. W. Trisunaryanti, I. I. Fallah, Sutarno, A. Ningtyas, F. Swasdika and D. A. Ratna, Int. J. ChemTech Res., 9, 96(2016).

3. A. Al Ifah, W. Trisunaryanti, Triyono and K. Dewi, Int. J. ChemTech Res., 9, 382(2016).

4. G. Muthu Kumaran, S. Garg, K. Soni, M. Kumar, J. K. Gupta, L. D. Sharma, K. S. Rama Rao and G. Murali Dhar, Microporous Mesoporous Mater., 114, 103(2008), DOI: 10.1016/j.micromeso.2007.12.021.

5. M. Pongsendana, W. Trisunaryanti, F. W. Artanti, I. I. Falah and Sutarno, Korean J. Chem. Eng., 34, 2591(2017), DOI: 10.1007/s11814-017-0165-3.

6. E. A. Karakhanov, A. P. Glotov, A. G. Nikiforova, A. V Vutolkina, A. O. Ivanov, S. V Kardashev, A. L. Maksimov and S. V Lysenko, Fuel Process. Technol., 153, 50(2016), DOI: 10.1016/j.fuproc.2016.07.023.

7. A. Masykuroh, W. Trisunaryanti, I. I. Falah and Sutarno, Int. J. ChemTech Res., 9, 598(2016).

8. I. Salim, W. Trisunaryanti, Triyono and Y. Arryanto, Int. J. ChemTech Res., 9, 492(2016).

9. Y. Zhao, Y. Zhang, Y. Wang, J. Zhang, Y. Xu, S. Wang and X. Ma, Appl. Catal. A, Gen., 539, 59(2017), DOI: 10.1016/j.apcata.2017.04.001.

10. X. Wang, G. Zhou, H. Zhang, S. Du, Y. Xu and C. Wang, J. Non. Cryst. Solids, 357, 3027(2011), DOI: $10.1016 /$ j.jnoncrysol.2011.04.009.

11. M. Ulfa, W. Trisunaryanti, I. I. Falah and I. Kartini, J. Kim. dan Pendidik. Kim., 1, 1 (2016).

12. W. Trisunaryanti, P. S. Lisna, I. Kartini, Sutarno, I. I. Falah and Triyono, Asian J. Chem., 28, 996 (2016), DOI: $10.14233 /$ ajchem.2016.19561.

13. M. Ulfa, W. Trisunaryanti, I. I. Falah and I. Kartini, IOSR J. Appl. Chem., 8, 57(2015), DOI: 10.9790/5736-08825763.

14. B. Xu, Y. Yang, Y. Xu, B. Han, Y. Wang, X. Liu and Z. Yan, Microporous Mesoporous Mater., 238, 
84(2017), DOI: 10.1016/j.micromeso.2016.02.031.

15. D. G. Kizzire, S. Dey, R. A. Mayanovic, R. Sakidja, K. Landskron, M. Mandal, Z. Wang and M. Benamara, Microporous Mesoporous Mater., 252, 69(2017),DOI: 10.1016/j.micromeso.2017.06.016.

16. W. Sriningsih, M. G. Saerodji, W. Trisunaryanti, Triyono, R. Armunanto and I. I. Falah, Procedia Environ. Sci., 20, 215(2014), DOI: 10.1016/j.proenv.2014.03.028.

17. H. Kusumastuti, W. Trisunaryanti, I. I. Falah and M. F. Marsuki, Rasayan J. Chem., 11, 522 (2018), DOI: $10.7324 /$ RJC.2018.1122061.

18. K. Wijaya, G. Baobalabuana, W. Trisunaryanti and A. Syoufian, Asian J. Chem., 25, 8981(2013), DOI: $10.14233 /$ ajchem.2013.14946.

19. F. W. Artanti, W. Trisunaryanti, M. Pongsendana, Triyono, I. I. Falah and M. F. Marsuki, Rasayan J. Chem., 11, 1433(2018), DOI: 10.31788/RJC.2018.1143073.

20. D. P. Upare, S. Park, M. S. Kim, J. Kim, D. Lee, J. Lee, H. Chang, W. Choi, S. Choi, Y. P. Jeon, Y. K. Park and C. W. Lee, J. Ind. Eng. Chem., 35, 99(2016), DOI: 10.1016/j.jiec.2015.12.020.

[RJC-5297/2019] 